\title{
Direct oxygen removal technique for recycling titanium using molten $\mathrm{MgCl}_{2}$ salt
}

\author{
Toru H. Okabe, ${ }^{* a}$ Yuki Hamanakat ${ }^{\mathrm{b}}$ and Yu-ki Taninouchic
}

Received 17th December 2015, Accepted 19th January 2016

DOI: $10.1039 / c 5 f d 00229 j$

Deoxidation of $\mathrm{Ti}$, or direct removal of $\mathrm{O}$ dissolved in metallic $\mathrm{Ti}$, is known to be extremely difficult when $\mathrm{Mg}$ is used as the deoxidizing agent. This difficulty arises because the chemical potential of $\mathrm{O}_{2}, p_{\mathrm{O}_{2}}$ under $\mathrm{Mg} / \mathrm{MgO}$ equilibrium is high (approximately $10^{-41} \mathrm{~atm}$ at $1200 \mathrm{~K}$ ) and is equivalent to that of $\mathrm{Ti}$ containing $\sim 2$ mass\% O at $1200 \mathrm{~K}$. Therefore, when deoxidizing Ti to the commercial level of high-grade pure $\mathrm{Ti}$ (below 0.05 mass\% O) using an $\mathrm{Mg}$ reductant at $1200 \mathrm{~K}$, the activity of the reaction product $\mathrm{MgO}\left(a_{\mathrm{MgO}}\right)$ must be decreased to below $\sim 0.025$, which is difficult in practice. In this study, the removal of $\mathrm{O}$ in $\mathrm{Ti}$ in molten $\mathrm{MgCl}_{2}$ salt using an electrochemical technique was examined at $\sim 1173 \mathrm{~K}$ with the objective of obtaining $\mathrm{Ti}$ containing less than 0.05 mass\% $\mathrm{O}$. $\mathrm{Ti}$ samples and graphite electrodes immersed in molten $\mathrm{MgCl}_{2}$ served as the cathode and anode, respectively. A constant voltage was applied between the electrodes using an external DC source. Molten $\mathrm{MgCl}_{2}$ was employed to produce the deoxidizing agent $\mathrm{Mg}$ and to facilitate deoxidation of $\mathrm{Ti}$ by decreasing the activity of the reaction product $\mathrm{MgO}$. By applying a voltage of approximately $3.1 \mathrm{~V}$ between the electrodes, the chemical potential of $\mathrm{Mg}$ in the molten $\mathrm{MgCl}_{2}$ was increased at the surface of the $\mathrm{Ti}$ cathode, and the $\mathrm{Ti}$ samples were deoxidized. The resulting $\mathrm{O}$ species, mainly formed $\mathrm{O}^{2-}$ dissolved in the molten $\mathrm{MgCl}_{2}$, was removed from the molten salt by reacting with the $\mathrm{C}$ anode to form $\mathrm{CO}\left(\mathrm{or} \mathrm{CO}_{2}\right.$ ) gas. Ti wires containing 0.12 mass $\%$ O were deoxidized to less than 0.02 mass\% $O$. In some cases, the $O$ concentration in the Ti samples was reduced to the level of 0.01 mass\%, which cannot be accomplished using the conventional Kroll process. The possible application of this deoxidation technique to practical industrial recycling processes is discussed.

\footnotetext{
International Research Center for Sustainable Materials, Institute of Industrial Science, The University of Tokyo, 4-6-1 Komaba, Meguro-ku, Tokyo 153-8505, Japan.E-mail: okabe@iis.u-tokyo.ac.jp ${ }^{b}$ Department of Materials Engineering, Graduate School of Engineering, The University of Tokyo, 7-3-1 Hongo, Bunkyo-ku, Tokyo, 113-8656, Japan

'Institute of Industrial Science, The University of Tokyo, 4-6-1 Komaba, Meguro-ku, Tokyo 153-8505, Japan $\dagger$ Currently at Mitsubishi Materials Corporation.
} 
In recent years, the recycling of $\mathrm{Ti}$ and $\mathrm{Ti}$ alloys has become an important issue., ${ }^{\mathbf{1 , 2}}$ The demand for Ti and Ti alloys in the aerospace industry is increasing, and large amounts of $\mathrm{Ti}$ scraps are generated from the fabrication of $\mathrm{Ti}$ and $\mathrm{Ti}$ alloy products. Fig. 1 shows the material flow of Ti in the US. ${ }^{1}$ The volume of scrap generated is greater than the volume of fabricated Ti products.

Commercial $\mathrm{Ti}$ and its alloys contain oxygen at approximately 0.1 mass\% (1000 mass ppm) as a major impurity. Oxygen contamination of the product must be avoided, because the presence of $\mathrm{O}$ deteriorates the mechanical properties of the metals. Table 1 shows the ASTM grades and acceptable impurity concentrations of Ti and its alloys. ${ }^{3}$ In producing commercially pure Ti of ASTM Gr. 1, lowO-containing Ti feed such as high-purity Ti sponge (0.03-0.1 mass\% O) produced by the Kroll process ${ }^{4}$ is used. Using large amounts of scrap metal to produce low-O Ti is hindered by the high O level in Ti scrap, which typically exceeds 0.1 mass $\%$. Titanium and its alloys containing more than 0.4 mass $\% \mathrm{O}$ cannot be recycled into titanium alloys, and these metals are mainly used in cascade recycling as additive elements for steel, aluminum, etc.

O removal directly from $\mathrm{Ti}$ and its alloys to levels below 0.1 mass $\%$ (1000 mass $\mathrm{ppm}$ ) is very difficult because $\mathrm{O}$ dissolves in Ti to form an interstitial solid solution, and because Ti has a strong affinity with 0.,5 Table 2 lists some effective methods for direct removal of $\mathrm{O}$ from Ti and from TiAl. ${ }^{2,6-48}$ For example, the deoxidation of solid Ti by reaction with chemically active Ca dissolved in $\mathrm{CaCl}_{2}$ in the temperature range of 1273 to $1473 \mathrm{~K}$ has been examined. Okabe et al. successfully produced $\mathrm{Ti}$ containing less than $50 \mathrm{ppm}$ by mass of $\mathrm{O}$ with a high residual resistivity ratio $(\mathrm{RRR}>120){ }^{18,19} \mathrm{Ca}$ metal is one of the most effective deoxidation agents because it has an extremely strong affinity for $\mathrm{O}$ and because it

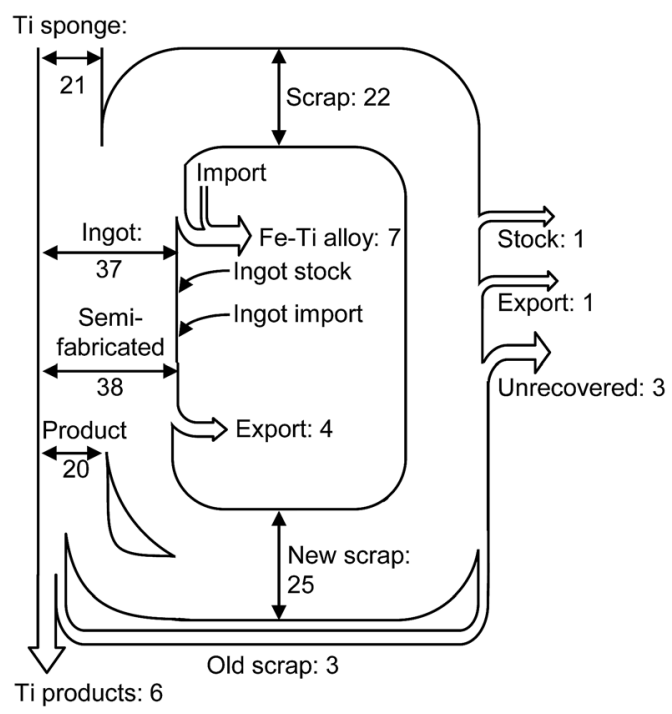

Fig. 1 Estimated material flow of titanium scrap in the U.S. in 2004. ${ }^{1}$ Units in the figure are $10^{3}$ ton. Values are rounded to the nearest thousand metric tons of contained titanium. 
Table 1 Grades and impurity concentrations of pure titanium and titanium alloys ${ }^{3}$

\begin{tabular}{llllllllll}
\hline & \multicolumn{7}{c}{ Concentration of element $i, C_{i}$ (mass\%) } \\
\cline { 3 - 9 } & Specification & $\mathrm{C}$ & $\mathrm{H}$ & $\mathrm{O}$ & $\mathrm{N}$ & $\mathrm{Fe}$ & $\mathrm{Al}$ & $\mathrm{V}$ \\
\hline \multirow{2}{*}{ Pure Ti } & ASTM Gr. 1 & $\leq 0.08$ & $\leq 0.015$ & $\leq 0.18$ & $\leq 0.03$ & $\leq 0.2$ & - & - \\
& ASTM Gr. 2 & $\leq 0.08$ & $\leq 0.015$ & $\leq 0.25$ & $\leq 0.03$ & $\leq 0.3$ & - & - \\
& ASTM Gr. 3 & $\leq 0.08$ & $\leq 0.015$ & $\leq 0.35$ & $\leq 0.05$ & $\leq 0.3$ & - & - \\
& ASTM Gr. 4 & $\leq 0.08$ & $\leq 0.015$ & $\leq 0.40$ & $\leq 0.05$ & $\leq 0.5$ & - & - \\
Ti-Al-V alloy & ASTM Gr. 5 & $\leq 0.08$ & $\leq 0.015$ & $\leq 0.20$ & $\leq 0.05$ & $\leq 0.40$ & $5.5-6.75$ & $3.5-4.5$ \\
& ASTM Gr. 23 & $\leq 0.08$ & $\leq 0.0125$ & $\leq 0.13$ & $\leq 0.03$ & $\leq 0.25$ & $5.5-6.5$ & $3.5-4.5$
\end{tabular}

has very low solubility in solid Ti. In the Ca-halide flux deoxidation process shown in Table 2, the $\mathrm{CaCl}_{2}$ flux contains the deoxidation agent $\mathrm{Ca}$ and facilitates the reaction by diluting the reaction product $\mathrm{CaO}$, thus decreasing the activity of the by-product. However, the purity of flux and the initial $\mathrm{O}$ content of the Ti are subject to limits, since the ultimate limit of deoxidation depends on the amounts of both $\mathrm{O}$ present as an impurity in the $\mathrm{CaCl}_{2}$ flux and $\mathrm{CaO}$ produced during deoxidation.

An effective technique for the preparation of $\mathrm{O}$-free $\mathrm{Ti}$ by electrochemical deoxidation using $\mathrm{CaCl}_{2}$ molten salt has been developed. ${ }^{21}$ Removal of $\mathrm{O}^{2-}$ (present as $\mathrm{CaO}$ in the flux) and production of Ca deoxidant using electrochemical techniques improved the deoxidation limit of the Ca-halide flux deoxidation process. Under certain conditions, Ti with 0.001 mass $\%$ (10 mass ppm) $\mathrm{O}$ has been successfully produced by the electrochemical deoxidation technique.

Hashimoto et al. proposed a method for the deoxidation of Ti during electrowinning using molten fluoride salt baths, ${ }^{45-47}$ but contamination of Ti by O or C is unavoidable using this method. In 2001, Chen et al. developed a novel process, called the FFC process, for producing Ti directly from $\mathrm{TiO}_{2}$ immersed in $\mathrm{CaCl}_{2}$ molten salt using electrochemical methods, and they succeeded in obtaining lowO Ti using this process. ${ }^{26-28}$ Ono and Suzuki developed a new Ti reduction process that utilizes electrochemically produced Ca reductant in molten $\mathrm{CaCl}_{2}$ salt. $^{32}$ To obtain low-O Ti, a highly reducing atmosphere is required. For this reason, molten $\mathrm{CaCl}_{2}$ with high metallic Ca activity is employed as the reaction medium. Other recent developments in deoxidation techniques for $\mathrm{Ti}$ and its alloys are also listed in Table 2.

Deoxidation of Ti using $\mathrm{Mg}$ as the deoxidizing agent is believed to be almost impossible. This is because the deoxidation limit of a Ti-O solid solution by $\mathrm{Mg}$ under $\mathrm{MgO}$ saturation is about 2 mass\% (20 000 mass ppm) at $1200 \mathrm{~K}$; reducing the deoxidation limit to the level of 100 mass ppm is difficult from a practical perspective. However, if deoxidation of Ti using a $\mathrm{MgCl}_{2}$ medium becomes feasible, the reduction and electrolysis facilities of the conventional Kroll process $^{4}$ could be utilized. Therefore, developing an effective deoxidation process for $\mathrm{Ti}$ and its alloys using molten $\mathrm{MgCl}_{2}$ is expected to significantly enhance the recovery rate for $\mathrm{Ti}$ scraps and the production of low-Ocontaining Ti. 
Table 2 Some examples of the upgrading process for titanium metal investigated in previous studies ${ }^{2,6-48}$

\begin{tabular}{llll}
\hline Method & Reference & $\begin{array}{l}\text { Advantages } \\
\text { (deox. limit) }\end{array}$ & Disadvantages \\
\hline
\end{tabular}

Deoxidation (Deox.)

Deox. by M/MOx eq. (DOSS

process)

Calcium halide

flux deox.

Electrochemical

deox.

FFC process

OS process

Deox. during EB remelting with $\mathrm{Al}$ VIM with $\mathrm{CaAl}_{2}$

PESR with $\mathrm{Ca}$ and $\mathrm{CaF}_{2}$ flux

Electric arc remelting under $\mathrm{H}_{2}-\mathrm{Ar}$ atmosphere

Deox. of Ti alloy by $\mathrm{HDH}$

\section{Others}

Electrorefining in molten salt
Oh et al. ${ }^{16}$ Roh et al. ${ }^{17}$

Ono and Miyazaki, ${ }^{6}$ Fisher, ${ }^{7-10}$

Okabe et al., ${ }^{11-14}$

Oh et al. ${ }^{15,16}$

Roh et al. ${ }^{17}$

Okabe et al. ${ }^{18-20}$

Okabe et al., ${ }^{21,22}$

Nakamura et al. ${ }^{23}$

Hirota et al.,$^{24}$

Taninouchi et al. ${ }^{25}$

Chen et al. ${ }^{26-28}$

Fray, ${ }^{29}$

Mohandas and

Fray, ${ }^{30}$

Tripathy et al. ${ }^{31}$

Ono and Suzuki, ${ }^{32}$

Suzuki et al. ${ }^{33-37}$

Yahata $e t a l .{ }^{38}$

Rotmann et al. ${ }^{2}$

Reitz et al. ${ }^{39}$

Su et $a l^{40}$

Nettle et al., ${ }^{41}$

Suchkov et al. ${ }^{42}$

Takeuchi et al., ${ }^{43,44}$

Hashimoto et al., ${ }^{45-47}$

Miyazaki et $a l^{48}$
Ti powder can be deoxidized.

( 500 ppm O)

High capability of deox. ( 50 ppm O)

Ultra-high capability of deox. $\mathrm{CaCl}_{2}$ bath ( $<10 \mathrm{ppm} \mathrm{O}), \mathrm{MgCl}_{2}$ bath (<100 ppm O) Production of lowoxygen titanium directly from oxides

Production of lowoxygen titanium directly from oxides Short processing time ( 100 ppm O) Short processing time ( 1500 ppm O) Short processing time ( 250 ppm O)

Short processing time ( 300 ppm O)

Simple process
Almost all impurities can be removed

Low capability of deox.

Not suitable for removing large amounts of $\mathrm{O}$. Leaching of molten salt bath is needed

Long processing time

Long processing time

Long processing time

Excess $\mathrm{Al}$ is contained in $\mathrm{Ti}$

Capability of deox. is

insufficient

Subsequent VAR is

required to remove

residual $\mathrm{Ca}$.

Applicability to

deoxidation of pure $\mathrm{Ti}$ is uncertain

Capability of deox. is

insufficient.

Applicability to deoxidation of pure $\mathrm{Ti}$ is uncertain Capability of deox. is insufficient

\section{Contamination from} molten salt. Difficulty of morphology control of Ti deposition 
Table 3 Some representative results for titanium deoxidation using various solid state deoxidation techniques

\begin{tabular}{|c|c|c|c|c|c|c|c|}
\hline \multirow[b]{2}{*}{ Method $^{a}$} & \multicolumn{3}{|c|}{ Oxygen (mass ppm) } & \multicolumn{3}{|c|}{ Nitrogen $^{c}$ (mass ppm) } & \multirow{2}{*}{$\begin{array}{l}\text { Note and references } \\
\text { (Exp. no.) }\end{array}$} \\
\hline & \multicolumn{2}{|l|}{ Init. } & After deox. & \multicolumn{2}{|l|}{ Init. } & After deox. & \\
\hline \multirow[t]{2}{*}{$\mathrm{Ca}-\mathrm{CaO}$} & 430 & $\rightarrow$ & 460 & 20 & $\rightarrow$ & 340 & \multirow{2}{*}{$\begin{array}{l}1273 \mathrm{~K}, 86 \mathrm{ks} \text {, ref. } 11 \\
\text { Eqn (3) }\end{array}$} \\
\hline & 1430 & $\rightarrow$ & 470 & 100 & $\rightarrow$ & 470 & \\
\hline \multirow[t]{2}{*}{$\mathrm{Y}-\mathrm{Y}_{2} \mathrm{O}_{3}$} & 200 & $\rightarrow$ & 120 & & N.A & & \multirow{2}{*}{$\begin{array}{l}1231 \mathrm{~K}, 260 \mathrm{ks}, \text { ref. } 12 \\
(\# 2 \mathrm{U})\end{array}$} \\
\hline & 1100 & $\rightarrow$ & 150,170 & & N.A & & \\
\hline \multirow[t]{3}{*}{$\mathrm{Y}-\mathrm{Y}_{2} \mathrm{O}_{3}$} & 210 & $\rightarrow$ & 90 & 10 & $\rightarrow$ & $(30)$ & \multirow{3}{*}{$\begin{array}{l}1213 \mathrm{~K}, 551 \mathrm{ks} \text {, ref. } 14 \\
(\# \mathrm{U})\end{array}$} \\
\hline & 950 & $\rightarrow$ & 100,220 & 20 & $\rightarrow$ & $(50)$ & \\
\hline & 670 & $\rightarrow$ & 80,100 & 30 & $\rightarrow$ & $(60)$ & \\
\hline \multirow[t]{3}{*}{$\mathrm{Y}-\mathrm{Y}_{2} \mathrm{O}_{3}$} & 210 & $\rightarrow$ & 40,80 & 10 & $\rightarrow$ & $(50)$ & \multirow{3}{*}{$\begin{array}{l}1173 \mathrm{~K}, 518 \mathrm{ks} \text {, ref. } 14 \\
(\# \mathrm{~T})\end{array}$} \\
\hline & 950 & $\rightarrow$ & 160,160 & 20 & $\rightarrow$ & $(120)$ & \\
\hline & 670 & $\rightarrow$ & 30,240 & 30 & $\rightarrow$ & $(80)$ & \\
\hline \multirow[t]{3}{*}{$\mathrm{Ca}-\mathrm{Y}-\mathrm{Y}_{2} \mathrm{O}_{3}$} & 210 & $\rightarrow$ & 130 & 10 & $\rightarrow$ & $(40)$ & \multirow{3}{*}{$\begin{array}{l}1173 \mathrm{~K}, 604 \mathrm{ks}, \text { ref. } 14 \\
(\# \mathrm{~W})\end{array}$} \\
\hline & 950 & $\rightarrow$ & 60,90 & 20 & $\rightarrow$ & $(50)$ & \\
\hline & 670 & $\rightarrow$ & 60,90 & 30 & $\rightarrow$ & $(120)$ & \\
\hline \multirow[t]{2}{*}{$\mathrm{Ca}-\mathrm{CaCl}_{2}$} & 130 & $\rightarrow$ & 16 & 10 & $\rightarrow$ & 41 & \multirow{2}{*}{$\begin{array}{l}1273 \mathrm{~K}, 90 \mathrm{ks}, \text { ref. } 19 \\
(\# 17 \mathrm{~B} 1) \\
\mathrm{RRR}_{4.2}{ }^{d}=98, \mathrm{Hv}^{e}=85\end{array}$} \\
\hline & 130 & $\rightarrow$ & 17 & 10 & $\rightarrow$ & 34 & \\
\hline \multirow[t]{2}{*}{$\mathrm{Ca}-\mathrm{CaCl}_{2}$} & 130 & $\rightarrow$ & 35 & 10 & $\rightarrow$ & 49 & \multirow{2}{*}{$\begin{array}{l}1373 \mathrm{~K}, 40 \mathrm{ks}, \text { ref. } 19 \\
(\# 19 \mathrm{~B} 1) \\
\mathrm{RRR}_{4.2}{ }^{d}=95, \mathrm{Hv}^{e}=92\end{array}$} \\
\hline & 130 & $\rightarrow$ & 22 & 10 & $\rightarrow$ & 45 & \\
\hline \multirow[t]{2}{*}{$\mathrm{Ca}-\mathrm{CaCl}_{2}$} & 150 & $\rightarrow$ & 62 & 10 & $\rightarrow$ & 86 & \multirow{4}{*}{$\begin{array}{l}1273 \mathrm{~K}, 86 \mathrm{ks} \text {, ref. } 19 \\
(\# 3 \mathrm{C}) \\
\mathrm{RRR}_{4.2}{ }^{d}=122, \mathrm{Hv}^{e}=82 \\
1223 \mathrm{~K}, 22 \mathrm{ks}, \text { ref. } 21 \\
\text { (\#49, contaminated by } \\
\text { carbon) }\end{array}$} \\
\hline & & & & & & & \\
\hline \multirow{2}{*}{$\begin{array}{l}\text { Electrochem. } \\
\left(\mathrm{CaCl}_{2}\right)^{b}\end{array}$} & 900 & $\rightarrow$ & $<10$ & 40 & $\rightarrow$ & 20 & \\
\hline & 1400 & $\rightarrow$ & $<10$ & 20 & $\rightarrow$ & 20 & \\
\hline \multirow{2}{*}{$\begin{array}{l}\text { Electrochem. } \\
\left(\mathrm{CaCl}_{2}\right)^{b}\end{array}$} & 110 & $\rightarrow$ & 10 & $<10$ & $\rightarrow$ & $<10$ & \multirow{2}{*}{$\begin{array}{l}1223 \mathrm{~K}, 27 \mathrm{ks}, \text { ref. } 23 \\
(\# 69, \text { carbon: } 20 \rightarrow 30, \\
50 \rightarrow 80 \mathrm{ppm}) \\
\mathrm{RRR}_{4.2}{ }^{d}=155, \mathrm{Hv}^{e}=64\end{array}$} \\
\hline & 900 & $\rightarrow$ & 20 & 30 & $\rightarrow$ & 50 & \\
\hline \multirow[t]{2}{*}{$\begin{array}{l}\text { Electrochem. } \\
\left(\mathrm{CaCl}_{2}\right)^{b}\end{array}$} & 210 & $\rightarrow$ & 40,50 & 10 & $\rightarrow$ & 10 & $\begin{array}{l}1189 \mathrm{~K}, 36 \mathrm{ks} \text {, ref. } 24 \\
(\# 12)\end{array}$ \\
\hline & \multicolumn{7}{|c|}{$\begin{array}{l}(\mathrm{O} \text { in Gd: } 2100 \rightarrow 10,50 \mathrm{ppm}, \mathrm{O} \text { in Tb: } 2600 \rightarrow 20,20 \mathrm{ppm}, \mathrm{O} \text { in Dy: } 2300 \rightarrow \\
20,30 \mathrm{ppm} \mathrm{O} \text { in Er: } 2800 \rightarrow 40,40 \mathrm{ppm}, \mathrm{O} \text { in Y: } 11200 \rightarrow 340,380 \mathrm{ppm})\end{array}$} \\
\hline \multirow{4}{*}{$\begin{array}{l}\text { Electrochem. } \\
\left(\mathrm{MgCl}_{2}\right)^{b}\end{array}$} & 110 & $\rightarrow$ & 100 & $<10$ & $\rightarrow$ & 40 & \multirow{2}{*}{$\begin{array}{l}1173 \mathrm{~K}, 86 \mathrm{ks}, \text { ref. } 23 \\
(\# 75, \text { carbon: } 20 \rightarrow 50 \\
50 \rightarrow 120 \mathrm{ppm})\end{array}$} \\
\hline & 900 & $\rightarrow$ & 60 & 30 & $\rightarrow$ & 70 & \\
\hline & 840 & $\rightarrow$ & 90 & 20 & $\rightarrow$ & 440 & $\begin{array}{l}1173 \mathrm{~K}, 86 \mathrm{ks} \text {, ref. } 25 \\
\left(\mathrm{D} 13 \_150121^{g}\right)\end{array}$ \\
\hline & 1200 & $\rightarrow$ & 270 & 40 & $\rightarrow$ & 260 & $\begin{array}{l}1173 \mathrm{~K}, 86 \mathrm{ks} \text {, ref. } 25 \\
\left(\mathrm{D} 15 \_150123^{h}\right)\end{array}$ \\
\hline
\end{tabular}

a "M-MOx": deoxidation by metal/metal oxide, "Ca- $\mathrm{CaCl}_{2}$ ": calcium-halide flux deoxidation, "Electrochem.": electrochemical deoxidation. ${ }^{b}$ Salt in parentheses shows molten salt used for electrochemical deoxidation. ${ }^{c}$ Values in parenthesis include uncertainties. ${ }^{d}$ Residual resistivity ratio, $\rho_{298} / \rho_{4.2}$, determined by measurement at 298 and $4.2 \mathrm{~K}$. ${ }^{e}$ Vickers micro hardness $\left(\mathrm{kg} \mathrm{f} \mathrm{mm}^{-2}\right)$, measured using $500 \mathrm{~g}$ load at room temperature. $f$ "N.A.": not analyzed or not reported. ${ }^{g} \mathrm{Ti}$ wire $(\phi 1.0 \mathrm{~mm})$ was used as sample. Oxygen and nitrogen contents were analyzed by KOBELCO Research Institute, Inc. ${ }^{h}$ Ti rod $(\phi 3.0 \mathrm{~mm})$ was used as sample. Oxygen and nitrogen contents were analyzed by KOBELCO Research Institute, Inc. 


\section{Principle}

Because the principle of electrochemical deoxidation of $\mathrm{Ti}$ has been reported in detail previously, ${ }^{5,21}$ the deoxidation process is only briefly outlined here. A solid $\mathrm{Ti}-\mathrm{O}$ solution is deoxidized by $\mathrm{Mg}$ in the following reaction:

$$
\mathrm{O}(\text { in } \mathrm{Ti})+\mathrm{Mg} \text { (in flux) }=\mathrm{MgO} \text { (in flux) }
$$

The equilibrium $\mathrm{O}$ concentration in $\mathrm{Ti}$ depends thermodynamically on the temperature $T$ according to the following equation,

$$
\left[\operatorname{mass}^{\circ} \% \mathrm{O}\right]=\left(a_{\mathrm{MgO}} / a_{\mathrm{Mg}}\right)\left(1 / f_{\mathrm{O}}\right) \exp \left(\Delta G^{\circ} / R T\right)
$$

where $\Delta G^{\circ}$ is the standard Gibbs free energy change associated with the reaction described by eqn (1), $a_{\mathrm{MgO}}$ and $a_{\mathrm{Mg}}$ are the activities of $\mathrm{MgO}$ and $\mathrm{Mg}$, respectively, and $f_{\mathrm{O}}$ is the activity coefficient of $\mathrm{O}$ in solid Ti.

Fig. 2 shows the binary phase diagram for the Ti-O system. ${ }^{49}$ The equilibrium $\mathrm{O}$ concentration of $\mathrm{Ti}$ under $\mathrm{Mg} / \mathrm{MgO}$ equilibrium at $1273 \mathrm{~K}$ is plotted as an open circle. For reference, the equilibrium $\mathrm{O}$ concentration of $\mathrm{Ti}$ under $\mathrm{Ca} / \mathrm{CaO}$ equilibrium at $1273 \mathrm{~K}$ is plotted as a filled circle (about 0.05 mass $\% \mathrm{O}$ ). The equilibrium $\mathrm{O}$ concentration under $\mathrm{Mg} / \mathrm{MgO}$ equilibrium is approximately 2.6 mass $\%$ ( $7.4 \mathrm{~mol} \%$ ) at $1273 \mathrm{~K}$. This shows that it is thermodynamically difficult to remove $\mathrm{O}$ directly from $\mathrm{Ti}$ to levels below $1 \mathrm{mass} \%$ by $\mathrm{Mg}$ deoxidant when the activity of $\mathrm{MgO}\left(a_{\mathrm{MgO}}\right)$ is high.

The $\mathrm{O}$ potentials of $\beta$-Ti-O solid solution at temperatures between 1173 and $1473 \mathrm{~K}$ have been determined, ${ }^{11}$ and the feasibility of preparing low-O Ti by decreasing the activity of the by-product $\mathrm{CaO}\left(a_{\mathrm{CaO}}\right)$ has been examined using various Ca-halide fluxes in the presence of Ca metal (Ca-halide flux deox. shown in

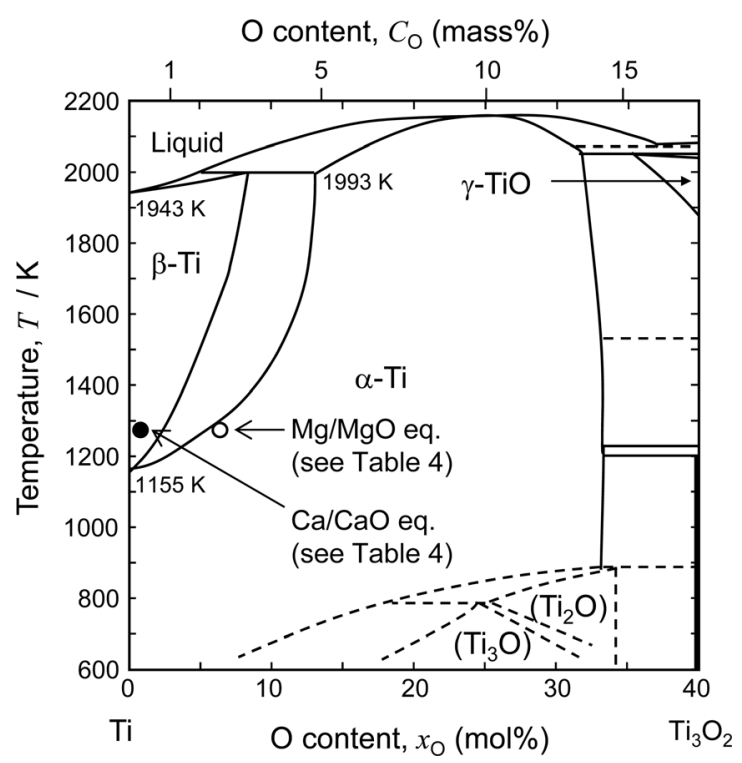

Fig. 2 Phase diagram of the $\mathrm{Ti}-\mathrm{O}$ binary system. ${ }^{49} \mathrm{Compositions}$ of $\mathrm{Ti}-\mathrm{O}$ solution under $\mathrm{Ca} / \mathrm{CaO}$ and $\mathrm{Mg} / \mathrm{MgO}$ equilibrium at $1273 \mathrm{~K}$ are plotted in the figure. 
Table 2). ${ }^{\mathbf{1 8 , 1 9}}$ Several factors have been considered in selecting a flux for deoxidation. $\mathrm{CaCl}_{2}$ has been found to be the most desirable flux at temperatures of $\sim 1300 \mathrm{~K}$ because the deoxidation product $\mathrm{CaO}$ dissolves easily in $\mathrm{CaCl}_{2}$ flux, which decreases its activity and thus lowers the limit of deoxidation. By submerging Ti wires and small pieces in Ca-saturated $\mathrm{CaCl}_{2}$, Ti samples has been deoxidized to a level of 50 mass ppm (see also Table 3). ${ }^{5,19}$

In the Ca-halide flux deoxidation method, the ultimate limit of deoxidation depends on the final $\mathrm{O}$ concentration in the flux, which means that the purity of the flux and the initial $\mathrm{O}$ content of the Ti will rule the deoxidation limit. To decrease the deoxidation limit set by $a_{\mathrm{CaO}}$, an electrochemical method was developed (electrochemical deox. shown in Table 2). ${ }^{21,22}$ The modified Ca-halide flux deoxidation method is characterized by both the production of Ca from the $\mathrm{CaCl}_{2}$ flux and the effective removal of $\mathrm{O}^{2-}$ (present as $\mathrm{CaO}$ ) dissolved in the flux by electrochemical means. In this method, as expressed in eqn (3), a Ti cathode is deoxidized by $\mathrm{Ca}$, which forms electrochemically on the surface of the cathode according to eqn (4). $\mathrm{O}^{2-}$ species in the flux are carried continuously to the $\mathrm{C}$ anode, and $\mathrm{O}$ in the flux is removed from the system as $\mathrm{CO}\left(\right.$ or $\left.\mathrm{CO}_{2}\right)$ gas by the anodic reaction expressed in eqn (5).

$$
\begin{gathered}
\mathrm{O} \text { (in } \mathrm{Ti})+\mathrm{Ca} \text { (in flux) }=\mathrm{Ca}^{2+} \text { (in flux) }+\mathrm{O}^{2-} \text { (in flux) } \\
\left.\mathrm{Ca}^{2+} \text { (in flux) }+2 e^{-}=\mathrm{Ca} \text { (on Ti cathode: in flux }\right) \\
\left.\mathrm{O}^{2-} \text { (in flux }\right)+\mathrm{C}(\mathrm{C} \text { anode })=\mathrm{CO} \text { (gas) }+2 e^{-}
\end{gathered}
$$

Unlike the Ca-halide flux deoxidation, the electrochemical method does not require the addition of metallic $\mathrm{Ca}$ as a deoxidant, because the activity of Ca near the cathode can be increased by controlling the applied voltage between the $\mathrm{Ti}$ cathode and the $\mathrm{C}$ anode. In some cases, $\mathrm{Ca}$ is precipitated on the cathode using an applied voltage exceeding the theoretical decomposition voltage of $\mathrm{CaCl}_{2}$ $(3.25 \mathrm{~V}$ at $1223 \mathrm{~K})$. Furthermore, $\mathrm{CaCl}_{2}$ flux can be purified through pre-electrolysis. This electrochemical method therefore has the advantage that contamination-free Ca deoxidant and $\mathrm{CaCl}_{2}$ flux can be used in the deoxidation process. By applying the electrochemical technique to molten $\mathrm{CaCl}_{2}$, Ti containing $\mathrm{O}$ below 10 mass ppm has been successfully produced under certain conditions. ${ }^{\mathbf{5} 21}$

In this study, the feasibility of the electrochemical deoxidation technique using $\mathrm{MgCl}_{2}$ as flux was examined. A schematic of the electrochemical deoxidation of $\mathrm{Ti}$ in molten $\mathrm{MgCl}_{2}$ is shown in Fig. 3 .

$$
\mathrm{O}(\text { in } \mathrm{Ti})+\mathrm{Mg} \text { (in flux) }=\mathrm{Mg}^{2+} \text { (in flux) }+\mathrm{O}^{2-} \text { (in flux) }
$$

Based on the thermodynamic calculation shown in Fig. $4,{ }^{5,11,50}$ when $a_{\mathrm{MgO}}$ is decreased to the level of $10^{-2}$ in the presence of metallic $\mathrm{Mg}$ at $1200 \mathrm{~K}$, the chemical potential of $\mathrm{O}_{2}\left(p_{\mathrm{O}_{2}}\right)$ in the system is decreased to $\sim 10^{-45} \mathrm{~atm}$, and Ti containing 0.018 mass $\%$ (180 mass ppm) O can be obtained. In other words, when $\mathrm{Ti}$ is deoxidized down to commercial O levels for high-grade $\mathrm{Ti}$ ( 0.05 mass\% $\mathrm{O}$, or 500 mass ppm) using $\mathrm{Mg}$ as reductant, $a_{\mathrm{MgO}}$ at $1200 \mathrm{~K}$ must be decreased to the level of 0.025 . 


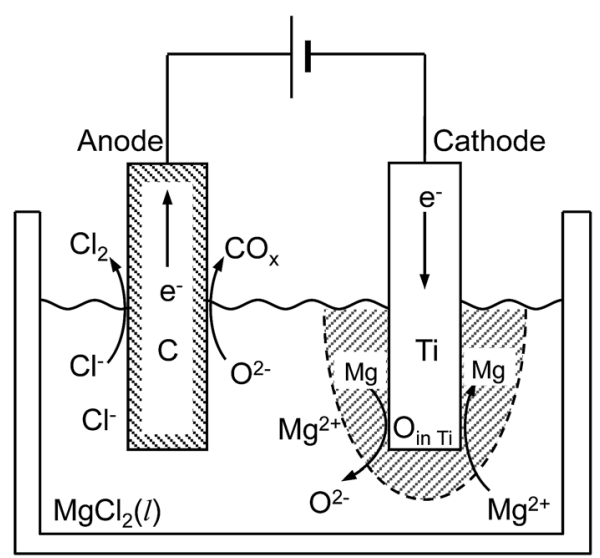

Fig. 3 Schematic illustration of electrochemical deoxidation in $\mathrm{MgCl}_{2}$ molten salt. Electrolysis is achieved using titanium as the cathode and carbon as the anode. At the cathode, a deoxidant of magnesium is produced by electrolysis, and the deoxidation product of magnesium oxide is dissolved in molten salt. At the anode, an oxide anion generated by the cathode is removed as carbon monoxide or dioxide gas. The anode reaction occurs in parallel with chlorine evolution. During this process, the activity of $\mathrm{MgO}$ can be kept at a low level on the cathode surface.

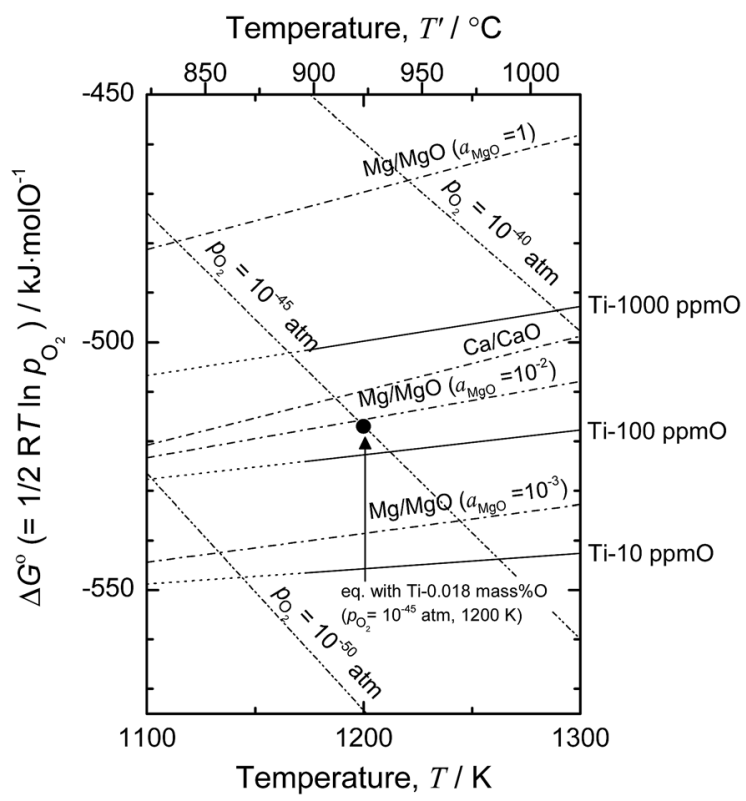

Fig. 4 Ellingham diagram of selected oxides $^{50}$ and solid solutions of Ti-O.,11 Oxygen chemical potential for Ti-0.018 mass $\% O\left(p_{\mathrm{O}_{2}}=10^{-45} \mathrm{~atm}\right)$ at $1200 \mathrm{~K}$ is plotted for reference.

\section{Experimental procedure}

Fig. 5 shows a flowchart of the experimental procedure for the electrochemical deoxidation of $\mathrm{Ti}$ in $\mathrm{MgCl}_{2}$. A schematic of the experimental apparatus used for 


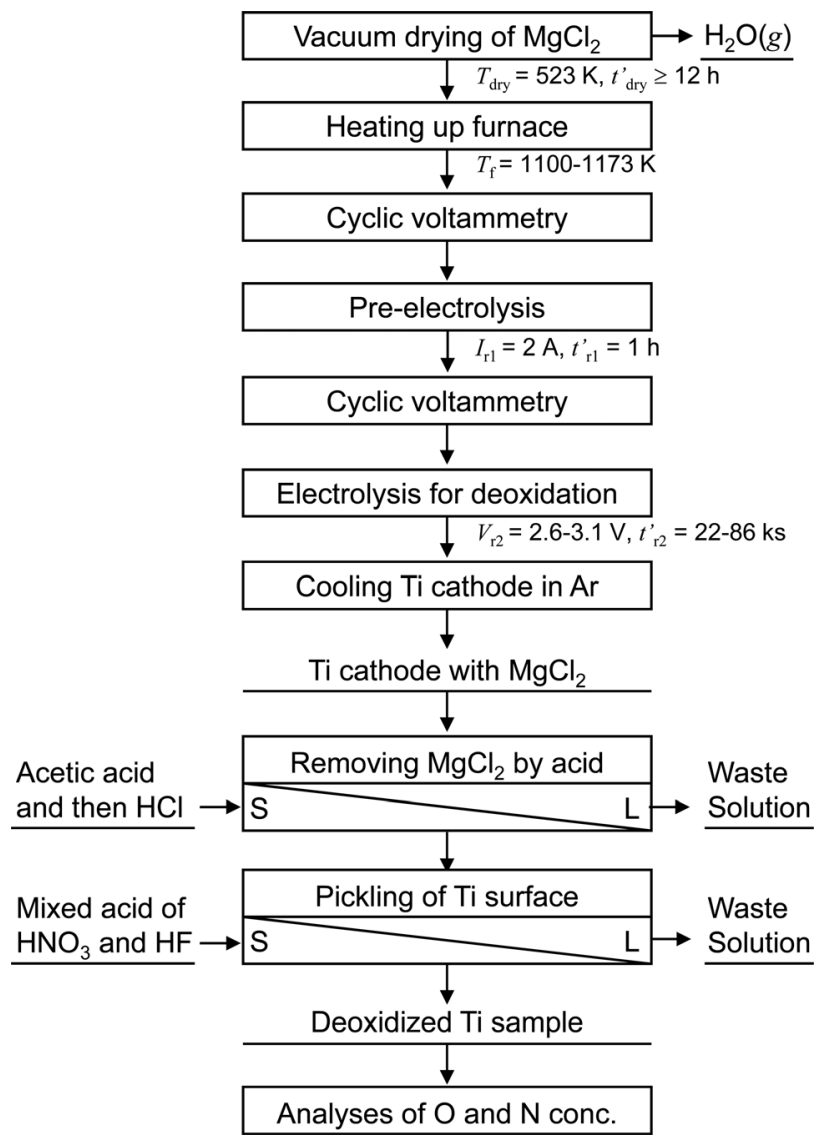

Fig. 5 Flowchart of experimental procedure for electrochemical deoxidation of titanium in molten $\mathrm{MgCl}_{2}$.

the electrochemical deoxidation of $\mathrm{Ti}$ in $\mathrm{MgCl}_{2}$ is shown in Fig. 6 . Ti in the form of small pieces and wires with different $\mathrm{O}$ concentrations and configurations was used as the starting material. The flux was reagent-grade anhydrous $\mathrm{MgCl}_{2}$ $(>97.0 \%)$ in flake form, dried at $523 \mathrm{~K}$ for more than $43 \mathrm{ks}(12 \mathrm{~h})$.

The dehydrated $\mathrm{MgCl}_{2}$ flux was contained in a Ti or mild steel crucible $(89 \mathrm{~mm}$ in diameter, $200 \mathrm{~mm}$ in height) and set in a gas-tight stainless steel chamber, as shown in Fig. 6 . The Ti cathode consisted of several strands of Ti wire $\sim 50 \mathrm{~mm}$ in length and $1 \mathrm{~mm}$ in diameter. The total electrode surface area was approximately $1000 \mathrm{~mm}^{2}$. In the same experiment, a Ti rod (approximately $30 \mathrm{~mm}$ in length, $3 \mathrm{~mm}$ in diameter) was used as the cathode. High-purity (99.9\%) graphite was used as the $\mathrm{C}$ anode (approximately $35 \mathrm{~mm}$ in length, 3 or $6 \mathrm{~mm}$ in diameter). These electrodes, as well as thermocouple tubing, were inserted into the reaction tube through a gas-tight water-cooled stainless steel head.

After the assembled cell was evacuated at $\sim 673 \mathrm{~K}$ to ensure a completely gastight and moisture-free system, Ar was introduced to the reaction tube. The furnace was then heated to a constant temperature between 1100 and $1173 \mathrm{~K}$. After the $\mathrm{MgCl}_{2}$ was melted, the graphite anode was inserted into the molten salt, 


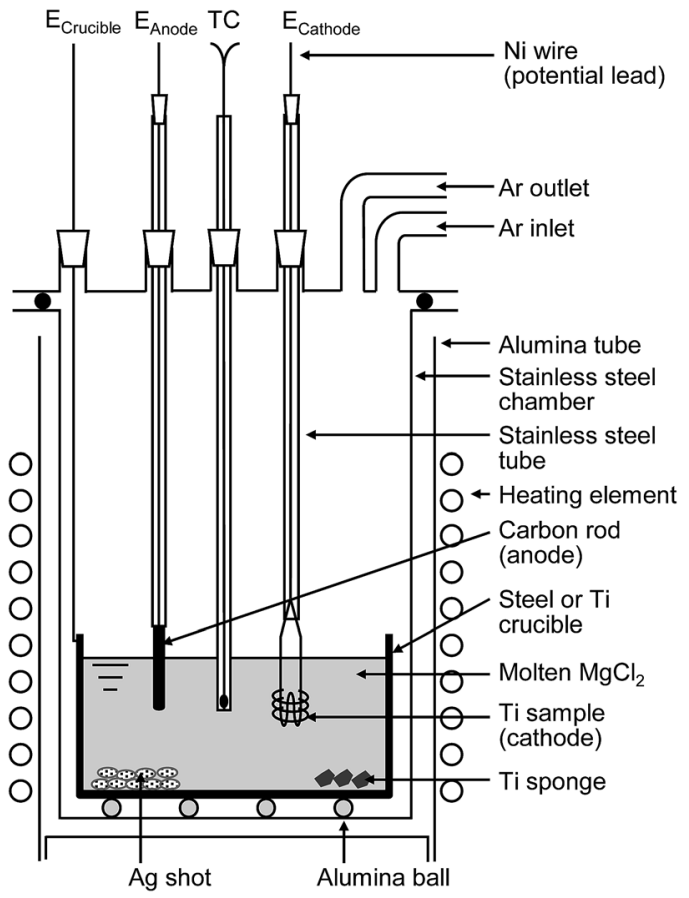

Fig. 6 Schematic illustration of experimental apparatus for electrochemical deoxidation of titanium in $\mathrm{MgCl}_{2}$.

and pre-electrolysis was conducted. In the pre-electrolysis, a 2 A current was passed for $\sim 3.6 \mathrm{ks}(1 \mathrm{~h})$ between the Ti crucible (or Ni electrode immersed in molten salt) and the $\mathrm{C}$ anode to eliminate residual metal and gaseous impurities in the molten salt. Approximately $50 \mathrm{~g}$ of silver was placed at the bottom of the crucible to absorb the magnesium metal deposited during electrolysis. The temperature of the molten salt was measured directly using a chromelalumel thermocouple protected by a stainless steel sheath. After pre-electrolysis, the Ti cathode containing the Ti samples was inserted into the molten $\mathrm{MgCl}_{2}$, and deoxidation experiments were performed by applying voltages between 0 and $3.1 \mathrm{~V}$ between the electrodes, which were separated by a distance of $\sim 30 \mathrm{~mm}$. In most cases, the deoxidation of the Ti cathode occurred with the application of voltages exceeding $2.6 \mathrm{~V}$ at $1100-1173 \mathrm{~K}$ for longer than $22 \mathrm{ks}$ (6 h).

Before and after the pre-electrolysis of $\mathrm{MgCl}_{2}$ and the deoxidation experiments, the electrochemical properties of the flux were measured by cyclic voltammetry (CV). An electrochemical interface (Solartron SI1287) was used for the CV measurements.

After the deoxidation experiment, the electrodes were removed from the molten $\mathrm{MgCl}_{2}$, and the cell was cooled in a stream of Ar gas. In some cases, only the Ti cathode was replaced after cooling for the next experimental run. The fused salt that adhered to the surface of the Ti electrode was removed by leaching with $(1+1)$ acetic acid, after which the Ti samples of the electrode were carefully 
cleaned in $(1+10)$ aqueous $\mathrm{HCl}$ solution, followed by water, alcohol, and acetone, and then dried.

The Ti samples obtained were subjected to $\mathrm{O}$ and $\mathrm{N}$ analyses using LECO analyzers. Prior to the analyses, the samples were surface-etched with a 1:4:10 mixture of $\mathrm{HF}-\mathrm{HNO}_{3}-\mathrm{H}_{2} \mathrm{O}$. To increase the accuracy of the $\mathrm{O}$ and $\mathrm{N}$ analyses, $1.1 \mathrm{~g}$ of nickel capsule containing $8.8 \pm 1.4 \mu \mathrm{g} \mathrm{O}$ and $0.2 \pm 0.2 \mu \mathrm{g} \mathrm{N}$ was used as an extraction bath for each $0.05-0.1 \mathrm{~g}$ Ti sample. The instrument for the $\mathrm{O}$ analysis was calibrated using Ti standard samples containing $470 \pm 30$ and $980 \pm$ 40 mass ppm $\mathrm{O}$.

\section{Results and discussion}

Fig. 7(a) shows the $\mathrm{CV}$ of the $\mathrm{MgCl}_{2}$ salt at $1173 \mathrm{~K}$ using a Ni quasi-reference before pre-electrolysis. The deposition of $\mathrm{Mg}$ occurs at approximately $-0.7 \mathrm{~V}$ with respect to the Ni quasi-reference, and gas evolution occurs at approximately $+1.6 \mathrm{~V}$. The

(a)

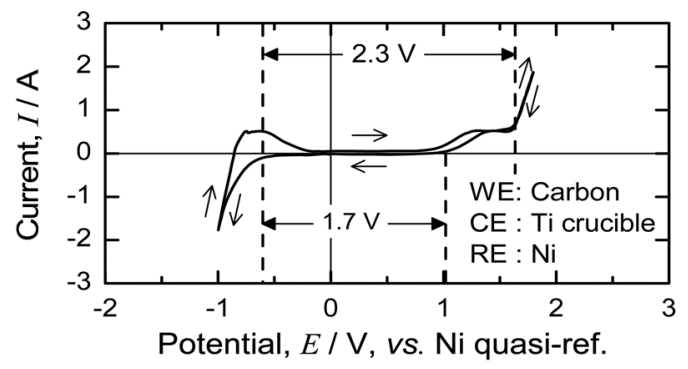

(b)

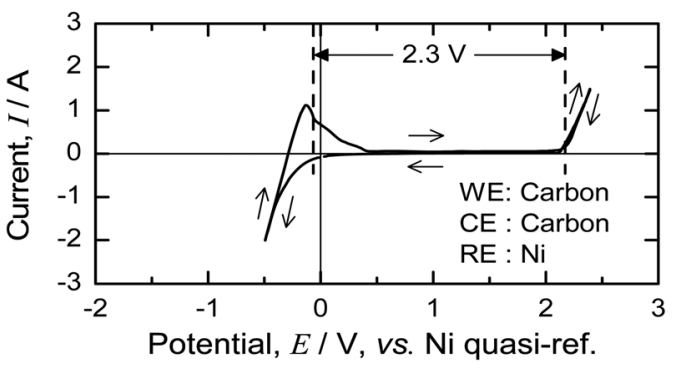

(c)

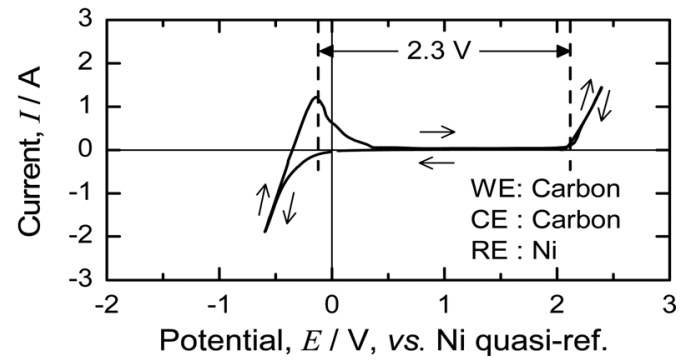

Fig. 7 Cyclic voltammograms in $\mathrm{MgCl}_{2}$ molten salt at $1173 \mathrm{~K}$. Surface area of electrode: $2 \mathrm{~cm}^{2}$ (C rod, Ni rod). Surface area of electrode: $260 \mathrm{~cm}^{2}$ (Ti crucible). Scan rate: $100 \mathrm{mV} \mathrm{s}^{-1}$. (a) Before pre-electrolysis. (b) After pre-electrolysis. (c) After electrolysis for Ti deoxidation. 
oxidation wave between 1 and $1.6 \mathrm{~V}$ probably results from oxygen impurities in the molten salt, and the gas evolution peak at $\sim 1.6 \mathrm{~V}$ corresponds to the evolution of $\mathrm{Cl}_{2}$ gas.

During pre-electrolysis using a Ni electrode as a cathode, $\mathrm{Mg}$ metal was electrochemically deposited on the Ni electrode. After pre-electrolysis, the $\mathrm{Mg}$ deposition and gas evolution peaks shifted to 0 and $2.3 \mathrm{~V}$, respectively. Fig. 7(b) and (c) show the $\mathrm{CV}$ of the molten $\mathrm{MgCl}_{2}$ before and after the deoxidation experiments. As the theoretical decomposition voltage of $\mathrm{MgCl}_{2}$ at $1173 \mathrm{~K}$ is $2.3 \mathrm{~V},{ }^{50}$ the reference electrode worked correctly, and the Ni quasi-reference electrode became a reference for $\mathrm{Mg} / \mathrm{Mg}^{2+}$ after pre-electrolysis.

The results shown in Fig. 7 indicate that the electrochemical properties of $\mathrm{MgCl}_{2}$ are unchanged before and after the deoxidation experiments. After preelectrolysis, only the $\mathrm{Mg}$ deposition wave and $\mathrm{Cl}_{2}$ evolution are observed, and therefore, the reaction system in the molten salt can be regarded as contamination-free $\mathrm{MgCl}_{2}$.

By applying a voltage of $\sim 3.1 \mathrm{~V}$ between the electrodes, the chemical potential of metallic $\mathrm{Mg}\left(a_{\mathrm{Mg}}\right)$ in $\mathrm{MgCl}_{2}$ was increased on the surface of the Ti cathode to a value approaching 1 , and the Ti samples were deoxidized by the electrochemically produced $\mathrm{Mg}$. The resulting $\mathrm{O}$ species, present mainly as $\mathrm{O}^{2-}$ dissolved in the molten $\mathrm{MgCl}_{2}$, reacted at the $\mathrm{C}$ anode to form $\mathrm{CO}\left(\right.$ or $\mathrm{CO}_{2}$ ) gas, which was removed from the molten salt system. For example, after electrochemical deoxidation at $1173 \mathrm{~K}$ for $86 \mathrm{ks}$, Ti wires $1.0 \mathrm{~mm}$ in diameter and containing 0.084 mass $\%$ (840 mass ppm) O were deoxidized to 0.009 mass\% (90 mass ppm) (Exp. no. D13_150121 shown in Table 3). ${ }^{25}$ When a Ti rod of $3.0 \mathrm{~mm}$ diameter containing 0.12 mass $\%$ (1200 mass ppm) O was deoxidized at $1173 \mathrm{~K}$ for $86 \mathrm{ks}$, Ti with 0.027 mass\% (270 mass ppm) O was obtained (Exp. no. D15_150123 shown in Table 3). ${ }^{25}$ The $\mathrm{N}$ concentration in the sample was increased from $\sim 10-40$ to $40-$ 440 mass ppm after deoxidation.

In Table 3, some representative analytical results for the $\mathrm{O}$ and $\mathrm{N}$ levels in $\mathrm{Ti}$ before and after deoxidation are listed, as well as results from previous studies. ${ }^{11,12,14,19,21,23-25}$ The analytical values below 0.01 mass\% (100 mass ppm) listed in the table include some uncertainty because gas analysis of Ti samples below 0.01 mass\% (100 mass ppm) is difficult. However, notably, Ti with an oxygen level of about 0.01 mass\% (100 mass ppm) was obtained by using $\mathrm{Mg}$ as the deoxidant when using the electrochemical technique.

Table 4 summarizes the deoxidation limits for the $\mathrm{Mg} / \mathrm{MgO}, \mathrm{Ca} / \mathrm{CaO}$, and $\mathrm{Y} / \mathrm{Y}_{2} \mathrm{O}_{3}$ systems. The activity of the metal oxides for obtaining Ti with 100 mass ppm $\mathrm{O}$ when using the respective metal deoxidants was calculated using the available thermodynamic data ${ }^{\mathbf{1 1 , 5 0}}$ and are listed in the table. In this study, Ti wires containing 0.12 mass $\%$ (1200 mass ppm) O were deoxidized to less than 0.02 mass\% (200 mass ppm) O. In some cases, the O concentration in the Ti samples was reduced to below 0.01 mass\% (100 mass ppm) O, which cannot be accomplished using the current Kroll process. These experimental results show that the activity of $\mathrm{MgO}, a_{\mathrm{MgO}}$, was decreased to below 0.01 .

When electrolysis in $\mathrm{CaCl}_{2}$ is utilized to remove $\mathrm{O}$ directly from $\mathrm{Ti}$, the deoxidation limit can be easily decreased to below 0.01 mass\% (100 mass ppm). However, after deoxidation, $\mathrm{CaCl}_{2}$ flux attached on the surface of Ti products must be removed by dissolving in aqueous solution, which causes $\mathrm{O}$ pickup. It is 
Table 4 Equilibrium oxygen concentrations calculated under $M / M O x$ equilibrium at $1273 \mathrm{~K}$ using available thermodynamic data. ${ }^{11,50}$ Calculated activities of metal oxides $\left(a_{\mathrm{MO}_{x}}\right)$ used to obtain low-oxygen-containing titanium (100 and 1000 mass ppm 0 ) are also shown for reference

\begin{tabular}{llll}
\hline & $\begin{array}{l}\text { Equilibrium O conc. } \\
\text { in Ti at 1273 K, } \\
C_{\mathrm{O} \text {,eq }}(\text { mass ppm) }\end{array}$ & $\begin{array}{l}\text { Required } a_{\mathrm{MO}_{x}} \text { to } \\
\text { obtain Ti with 1000 } \\
\text { ppm O at 1273 K, } a_{\mathrm{MO}_{x}}\end{array}$ & $\begin{array}{l}\text { Required } a_{\mathrm{MO}_{x}} \text { to } \\
\text { obtain Ti with 100 ppm } \\
\text { O at 1273 K, } a_{\mathrm{MO}_{x}}\end{array}$ \\
\hline $\mathrm{Mg} / \mathrm{MgO}$ & 26000 & 0.039 & 0.0039 \\
$\mathrm{Ca} / \mathrm{CaO}$ & 500 & 2.0 & 0.20 \\
$\mathrm{Y} / \mathrm{YO}_{1.5}$ & 180 & 13 & 0.41
\end{tabular}

impractical to remove $\mathrm{CaCl}_{2}$ by evaporation, because the vapor pressure of $\mathrm{CaCl}_{2}$ is low even at elevated temperatures. Fig. 8 shows the temperature dependence of the vapor pressures of $\mathrm{CaCl}_{2}$ and $\mathrm{MgCl}_{2} \cdot{ }^{50}$ The vapor pressure of $\mathrm{MgCl}_{2}$ is two or three orders of magnitude higher than that of $\mathrm{CaCl}_{2}$. The high vapor pressure of $\mathrm{MgCl}_{2}$ might enhance operational challenges during electrolysis. ${ }^{51}$ However, $\mathrm{MgCl}_{2}$ can be removed directly from titanium products by vacuum treatment; a technique for $\mathrm{MgCl}_{2}$ removal via vacuum distillation is already established in the Kroll process. This $\mathrm{MgCl}_{2}$ removal technique can easily be applied to the deoxidation process investigated in this study.

Fig. 9 shows the new recycling process for Ti scrap using electrochemical deoxidation in molten $\mathrm{MgCl}_{2}$ followed by the removal of $\mathrm{MgCl}_{2}$ by vacuum distillation. The reduction chamber used in the conventional Kroll process can be utilized in the electrochemical deoxidation process, as schematically shown in

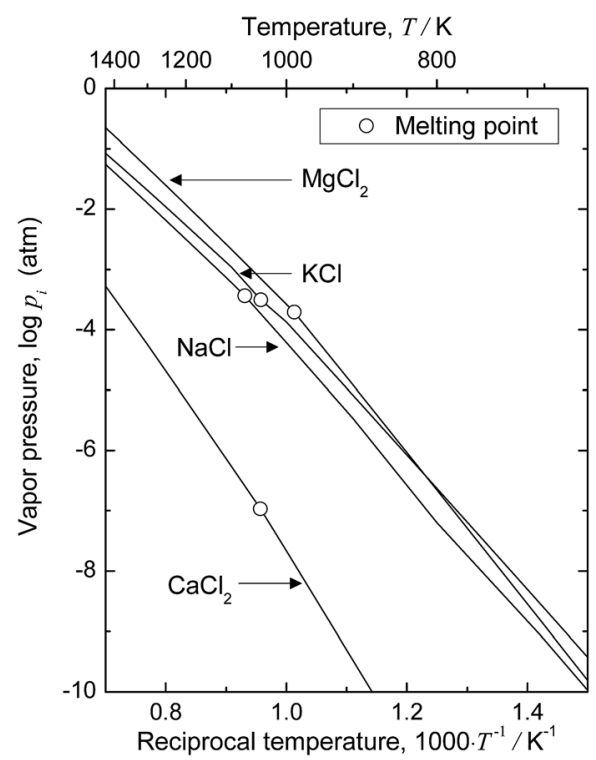

Fig. 8 Vapor pressures of metal chlorides as functions of reciprocal temperature. ${ }^{50}$ 


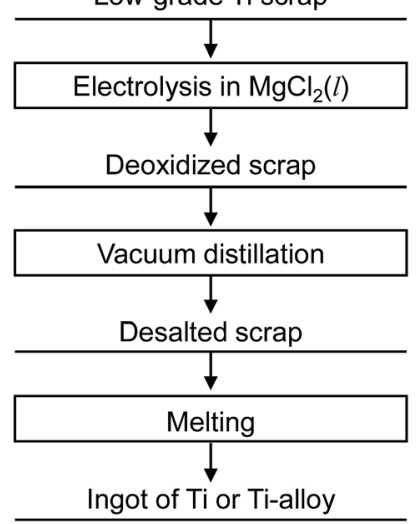

Fig. 9 Recycling process proposed in this study. Oxygen dissolved in Ti scrap is directly removed by molten salt electrolysis in $\mathrm{MgCl}_{2}$.

Fig. 10. As Ti production is increased, scrap treatment becomes increasingly important. In the future, the direct $\mathrm{O}$ removal technique proposed in this study may be applied to recycling Ti scrap.

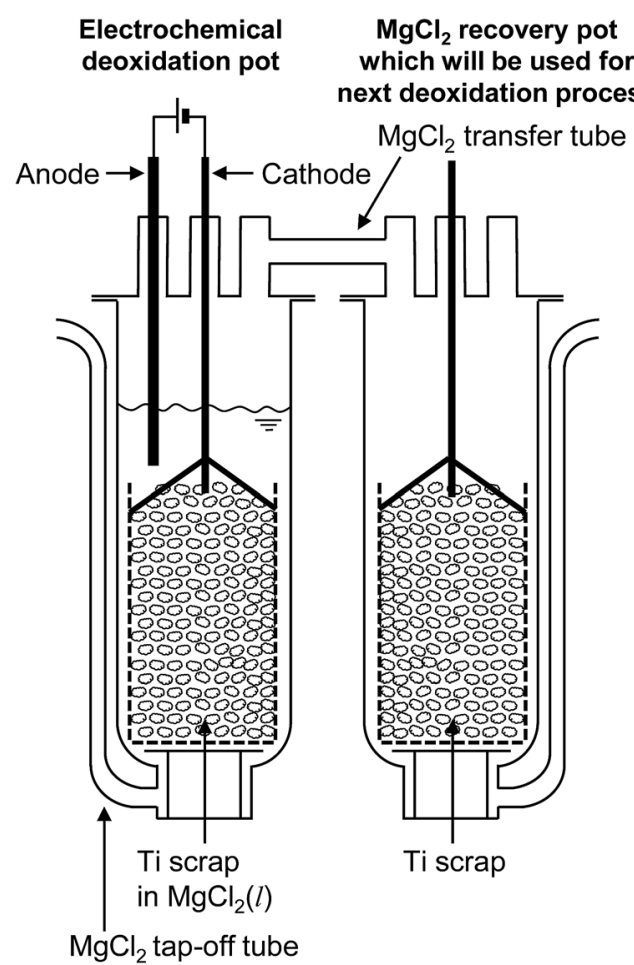

Fig. 10 Industrial application of the recycling process based on electrolysis in $\mathrm{MgCl}_{2}$. Process is feasible in existing Ti smelters based on the Kroll process. 


\section{Conclusions}

The removal of $\mathrm{O}$ from Ti using an electrochemical technique in molten $\mathrm{MgCl}_{2}$ was examined at temperatures of $\sim 1173 \mathrm{~K}$. The activity of $\mathrm{Mg}$ was increased near the Ti cathode surface and the activity of $\mathrm{MgO}$ was decreased by applying voltages between the Ti cathode and $\mathrm{C}$ anode immersed in molten $\mathrm{MgCl}_{2}$. These activity changes facilitated the deoxidation of a Ti cathode consisting of the Ti samples. A Ti sample containing approximately 1000 mass ppm $\mathrm{O}$ were deoxidized to less than 200 mass ppm by applying $3.1 \mathrm{~V}$ between the Ti and C electrodes for $86 \mathrm{ks}$. In some cases, the $\mathrm{O}$ concentration in Ti was decreased to below 100 mass ppm, which cannot be accomplished using the conventional Kroll process. The application of this deoxidation technique to industrial recycling processes may become practical in the future.

\section{Acknowledgements}

The authors are grateful to Professor Masafumi Maeda and Professor Kazuki Morita of The University of Tokyo and to Dr Tetsushi Deura, and Messrs. Daisuke Matsuwaka and Fumiaki Kudo of Kobe Steel, Ltd. for their sample analysis. The authors thank Dr Katsuhiro Nose and Mr Hisao Kimura for their valuable suggestions and technical assistance. This research was partly funded by a Grantin-Aid for the Next Generation of World-Leading Researchers (NEXT Program) for the Research Project for Development of Environmentally Sound Recycling Technology of Rare Metals (NEXT Program \#GR019), and a Grant-in-Aid for Scientific Research (S) (KAKENHI Grant \#26220910) by JSPS.

\section{References}

1 T. G. Goonan, Titanium Recycling in the United States in 2004, Flow studies for recycling metal commodities in the United States, ed. S. F. Sibley, U. S. Geological Survey Circular, 1196, 2010, ch. Y, pp. Y1-Y16.

2 B. Rotmann, C. Lochbichler and B. Friedrich, Challenges in Titanium Recycling-Do We Need a New Specification for Secondary Alloys?, Proceedings of EMC 2011, 2011.

3 American Society for Testing and Materials, Standard Specification for Titanium and Titanium Alloy Strip, Sheet, and Plate, B265-06b, ASTM International, West Conshohocken, PA, 2006.

4 W. Kroll, The Production of Ductile Titanium, Trans. Electrochem. Soc., 1940, 78, 35-47.

5 T. H. Okabe, K. T. Jacob and Y. Waseda, Removal of Oxygen in Reactive Metals, in Purification Process and Characterization of Ultra High Purity Metals, ed. Y. Waseda and M. Isshiki, Springer, Berlin, 2001, pp. 3-37.

6 K. Ono and S. Miyazaki, Study on the Limit of Deoxidation of Titanium and the Reduction of Titanium Dioxide by Saturated Calcium Vapors, J. Jpn. Inst. Met., 1985, 49(10), 871-875, (in Japanese).

7 R. L. Fisher, Deoxidation of Titanium and Similar Metals Using a Deoxidant in a Molten Metal Carrier, US Pat. No. 4923531A, 1990, (UK Patent No. GB 2224749A, 1989).

8 R. L. Fisher, Deoxidation of a Refractory Metal, US Pat. No. 5022935, 1991. 
9 R. L. Fisher and S. R. Seagle, Removal of Oxide Layers from Titanium Castings Using an Alkaline Earth Deoxidizing Agent, US Patent No. 5211775 A, 1993.

10 R. L. Fisher and S. R. Seagle, DOSS, An Industrial Process for Removing Oxygen From Titanium Turnings Scrap, Titanium Science and Technology, ed. F. H. Froes and I. Caplan, The Minerals, Metals \& Materials Society (Proceedings of the 7th World Conference on Titanium, 1992), 1993, vol. 3, pp. 2265-2272.

11 T. H. Okabe, R. O. Suzuki, T. Oishi and K. Ono, Thermodynamic Properties of Dilute Titanium-Oxygen Solid Solution in Beta Phase, Mater. Trans. JIM, 1991, 32(5), 485-488.

12 T. H. Okabe, T. Deura, T. Oishi, K. Ono and D. R. Sadoway, Thermodynamic Properties of Oxygen in Yttrium Solid Solution, Metall. Trans. B, 1996, 27B, 841-847.

13 T. H. Okabe, K. Hirota, Y. Waseda and K. T. Jacob, Thermodynamic Properties of Oxygen in $\mathrm{Ln}-\mathrm{O}(\mathrm{Ln}=\mathrm{La}, \mathrm{Pr}, \mathrm{Nd})$ Solid Solutions and Their Deoxidation by Molten Salt Electrolysis, J. MMIJ, 1998, 114(11), 813-818.

14 T. H. Okabe, K. Hirota, E. Kasai, F. Saito, Y. Waseda and K. T. Jacob, Thermodynamic Properties of Oxygen in $\mathrm{RE}-\mathrm{O}(\mathrm{RE}=\mathrm{Gd}$, Tb, Dy, Er) Solid Solutions, J. Alloys Compd., 1998, 279, 184-191.

15 J.-M. Oh, B.-K. Lee, C.-Y. Suh, S.-W. Cho and J.-W. Lim, Preparation Method of Ti Powder with Oxygen Concentration of $<1000$ ppm Using Ca, Powder Metall., 2012, 55(5), 402-404.

16 J.-M. Oh, K.-M. Roh, B.-K. Lee, C.-Y. Suh, W. Kim, H. Kwon and J.-W. Lim, Preparation of Low Oxygen Content Alloy Powder from Ti Binary Alloy Scrap by Hydrogen-Dehydrogenation and Deoxidation Process, J. Alloys Compd., 2014, 593, 61-66.

17 K.-M. Roh, C.-Y. Suh, J.-M. Oh, W. Kim, H. Kwon and J.-W. Lim, Comparison of Deoxidation Capability for Preparation of Low Oxygen Content Powder from TiNi Alloy Scraps, Powder Technol., 2014, 253, 266-269.

18 T. H. Okabe, R. O. Suzuki, T. Oishi and K. Ono, Preparation of Extra Low Oxygen Titanium by Calcium-Halide Flux Deoxidation, J. Iron Steel Inst. Jpn., 1991, 77(1), 93-99, (in Japanese).

19 T. H. Okabe, T. Oishi and K. Ono, Preparation and Characterization of ExtraLow-Oxygen Titanium, J. Alloys Compd., 1992, 184, 43-56.

20 T. H. Okabe, T. Oishi and K. Ono, Deoxidation of Titanium Aluminide by Ca-Al Alloy under Controlled Aluminum Activity, Metall. Trans. B, 1992, 23B, 583590.

21 T. H. Okabe, M. Nakamura, T. Oishi and K. Ono, Electrochemical Deoxidation of Titanium, Metall. Trans. B, 1993, 24B, 449-455.

22 T. H. Okabe, T. Deura, T. Oishi, K. Ono and D. R. Sadoway, Electrochemical Deoxidation of Yttrium-Oxygen Solid Solution, J. Alloys Compd., 1996, 237, 150-154.

23 M. Nakamura, T. H. Okabe, T. Oishi and K. Ono, Electrochemical Deoxidation of Titanium, Proc. Int. Symp. Molten Salt Chem. Technol., 1993, 529-540.

24 K. Hirota, T. H. Okabe, F. Saito, Y. Waseda and K. T. Jacob, Electrochemical Deoxidation of RE-O (RE = Gd, Tb, Dy, Er) Solid Solution, J. Alloys Compd., 1999, 282, 101-108.

25 Y. Taninouchi, Y. Hamanaka and T. H. Okabe, submitted. 
26 G. Z. Chen, D. J. Fray and T. W. Farthing, Direct Electrochemical Reduction of Titanium Dioxide to Titanium in Molten Calcium Chloride, Nature, 2000, 407(6802), 361-364.

27 G. Z. Chen, D. J. Fray and T. W. Farthing, Cathodic Deoxidation of the Alpha Case on Titanium and Alloys in Molten Calcium Chloride, Metall. Trans. B, 2001, 32B, 1041-1052.

28 G. Z. Chen, D. J. Fray and T. W. Farthing, Removal of Oxygen from Metal Oxides and Solid Solutions by Electrolysis in a Fused Salt, US Pat. No. 2004/ 0159559 A1, 2004.

29 D. J. Fray, Emerging Molten Salt Technologies for Metals Production, JOM, 2001, 53(10), 26-31.

30 K. S. Mohandas and D. J. Fray, FFC Cambridge Process and Removal of Oxygen from Metal-Oxygen Systems by Molten Salt Electrolysis: an Overview, Trans. Indian Inst. Met., 2004, 57(6), 579-592.

31 P. K. Tripathy, M. Gauthier and D. J. Fray, Electrochemical Deoxidation of Titanium Foam in Molten Calcium Chloride, Metall. Trans. B, 2007, 38B, 893-900.

32 K. Ono and R. O. Suzuki, A New Concept for Producing Ti Sponge: Calciothermic Reduction, JOM, 2002, 54(2), 59-61.

33 R. O. Suzuki and S. Inoue, Calciothermic Reduction of Titanium Oxide in Molten $\mathrm{CaCl}_{2}$, Metall. Trans. B, 2003, 34B(3), 277-285.

34 R. O. Suzuki, K. Ono and K. Teranuma, Calciothermic Reduction of Titanium Oxide and In-situ Electrolysis in Molten $\mathrm{CaCl}_{2}$, Metall. Trans. B, 2003, 34B(3), 287-295.

35 R. O. Suzuki and S. Fukui, Reduction of $\mathrm{TiO}_{2}$ in $\mathrm{Molten}^{\mathrm{CaCl}_{2}}$ by Ca Deposited during CaO Electrolysis, Mater. Trans., 2004, 45(5), 1665-1671.

36 R. O. Suzuki, Calciothermic Reduction of $\mathrm{TiO}_{2}$ and In-situ Electrolysis of $\mathrm{CaO}$ in Molten $\mathrm{CaCl}_{2}$, J. Phys. Chem. Solids, 2005, 66(2), 461-465.

37 R. O. Suzuki, Direct Reduction Process for Titanium Oxide in Molten Salt, JOM, 2007, 59(1), 68-71.

38 T. Yahata, T. Ikeda and M. Maeda, Deoxidation of Molten Titanium by Electron-Beam Remelting Technique, Metall. Trans. B, 1993, 24B, 599-604.

39 J. Reitz, C. Lochbichler and B. Friedrich, Recycling of Gamma Titanium Aluminide Scrap from Investment Casting Operations, Intermetallics, 2011, 19, 762-768.

40 Y. Su, L. Wang, L. Luo, X. Jiang, J. Guo and H. Fu, Deoxidation of Titanium Alloy Using Hydrogen, Int. J. Hydrogen Energy, 2009, 34, 8958-8963.

41 J. R. Nettle, D. H. Baxer Jr and F. S. Wartman, Electrorefining Titanium Metal, United States Bureau of Mines, Report of Investigations 5315, Washington, D.C., U.S., 1957.

42 A. B. Suchkov, Z. A. Tubyshki, Z. I. Sokolova and N. V. Zhukova, Electrolytic Refining of Titanium Alloy Scrap Using Solid Intermediate Electrodes, Russ. Metall., 1969, 6, 52.

43 S. Takeuchi and O. Watanabe, Studies on the Method for the Electro-Refining of Titanium from the Molten Salts (1) Effect of the Various Molten Salt Baths on the Electro-Refining, J. Jpn. Inst. Met., 1964, 28(10), 633-638, (in Japanese).

$44 \mathrm{~S}$. Takeuchi and O. Watanabe, The Investigation on the Electrorefining of Titanium from the Molten Salts (II) Crystal Shapes and Growth of Titanium 
from the Various Molten Salt in the Electro-refining, J. Jpn. Inst. Met., 1964, 28(11), 728-734, (in Japanese).

45 Y. Hashimoto, K. Uriya and R. Kono, Electro-winning of Titanium Metal from Its Oxide by Fused Salt Electrolysis at Temperatures above the Melting Point of the Metal, Denki Kagaku, 1971, 39(6), 516-522, (in Japanese).

46 Y. Hashimoto, Influences of Fluoride Salt Baths on Fused-Salt Electrodeposition of Titanium Metal from $\mathrm{TiO}_{2}$, Denki Kagaku, 1971, 39(12), 938-943, (in Japanese).

$47 \mathrm{Y}$. Hashimoto, Electro-Winning of Titanium from $\mathrm{TiO}_{2}$ or $\mathrm{CaTiO}_{3}$ in $\mathrm{CaF}_{2}{ }^{-}$ $\mathrm{MgF}_{2}$ Molten Salt Bath, Denki Kagaku, 1972, 40(1), 39-44, (in Japanese).

48 H. Miyazaki, Y. Yamakoshi and Y. Shindo, Electrorefining of Titanium in Molten Salts, Mater. Jpn., 1994, 33(1), 51-54, (in Japanese).

49 T. B. Massalski, Binary Alloy Phase Diagrams, ASM international, Materials Park, OH, United States of America, 2nd edn, 1990.

50 I. Barin, Thermochemical Data of Pure Substances, VCH Verlagsgesellschaft mbH, Weinheim, Germany, 3rd edn, 1995.

51 W. Li, Y. Yuan, X. Jin, H. Chen and G. Z. Chen, Environmental and Energy Gains from Using Molten Magnesium-sodium-potassium Chlorides for Electro-metallisation of Refractory Metal Oxides, Prog. Nat. Sci., 2015, 25(6), 650-653. 